\title{
Migration of Ventriculoperitoneal Shunt Catheter into the Scrotum: A Case Report and Literature Review
}

\author{
Antônio Gilson Prates Júnior ${ }^{1}$, Fernando Augusto Medeiros Carrera Macedo², Emmanuel \\ de Oliveira Vasconcelos e Sá2 ${ }^{\text {, Ana Luisa Ribeiro Pinto }}{ }^{3}$
}

Received: 04 April 2020 / Published: 18 June 2020

\section{Abstract}

Introduction: The ventriculoperitoneal shunt is the most widely used surgical procedure for the treatment of hydrocephalus. It is associated with numerous mechanical complications, including distal catheter migration.

Case report: We present a case in which the peritoneal catheter migrated into the scrotum. The patient was admitted with asymmetric scrotal swelling and, during hospitalization, developed shunt dysfunction and infection. The shunt was withdrawn and treatment was initiated for infection. At the end of treatment, a new shunt was implanted and bilateral hernioplasty was performed by the pediatric surgery team. At follow-up, there was adequate head circumference growth and no testicular abnormalities.

Discussion: The procesus vaginalis is formed from the evagination of the peritoneum through the inguinal canal, leading to the descent of the testis during the embryonic period. The patency of this structure is the predisposing anatomical condition for the occurrence of inguinal hernia and for the migration of the shunt catheter into the scrotum. This condition is present in up to $80 \%$ of newborns and $60 \%$ of 1 -year-old infants. The migration of the catheter commonly occurs until 12 months after surgery, typically on the right side.

Conclusion: The presence of scrotal swelling in a patient with ventriculoperitoneal shunt should warrant the investigation of catheter migration.

Key words: Catheter migration, hydrocele, inguinal hernia, scrotum, ventriculoperitoneal shunt.

${ }^{1}$ Neurosurgeon, Rede Mater Dei de Saúde, Belo Horizonte, Minas Gerais, Brazil

${ }^{2}$ Neurosurgery Resident, Hospital das Clínicas, Universidade Federal de Minas Gerais, Belo Horizonte, Minas Gerais, Brazil

${ }^{3}$ Medical Student, Universidade Federal de Ouro Preto, Ouro Preto, Minas Gerais, Brazil

To whom correspondence should be addressed: Antônio Gilson Prates Júnior, MD. [E-mail: antonio.ufop@gmail.com]

Journal homepage: www.sbnped.com.br

\section{Introduction}

Ventriculoperitoneal shunt (VPS) is one of the most commonly performed neurosurgical procedures and the most used one in the treatment of hydrocephalus. It is associated with numerous mechanical complications such as obstruction, catheter fracture, disconnection, perforation of structures and migration1,2,3,4,5. Scrotal migration of the catheter is a rare complication, which can cause shunt dysfunction and scrotal abnormalities 1,6.

We present a case in which the peritoneal catheter of the VPS migrated to the scrotum. In addition, a literature review was performed in the PubMed database using the terms "ventriculoperitoneal shunt," "VP shunt," and "scrotum."

\section{Case report}

A 46-day-old infant, with a previous history of VPS on day 3 after birth, was admitted with intermittent left scrotal swelling (Figure 1). The patient was a 35-week and 5-day pre-term newborn with congenital

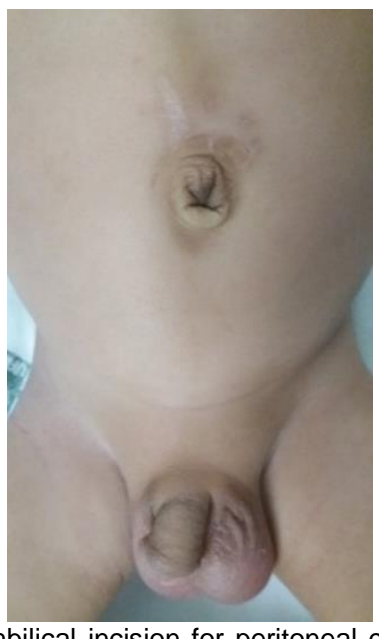

Figure 1. Supra-umbilical incision for peritoneal catheter implant. Note the slight testicular asymmetry with swelling on the left side 
hydrocephalus diagnosed by obstetric ultrasound. Physical examination revealed discrete scrotal asymmetry and a palpable malleable tubular structure in the left scrotum. The head circumference was within expected range and the anterior fontanelle was flat and normotensive. Abdominal radiographs and scrotal ultrasound showed the distal catheter within the scrotum on the left side associated with mild bilateral hydrocele (Figures 2 and 3).

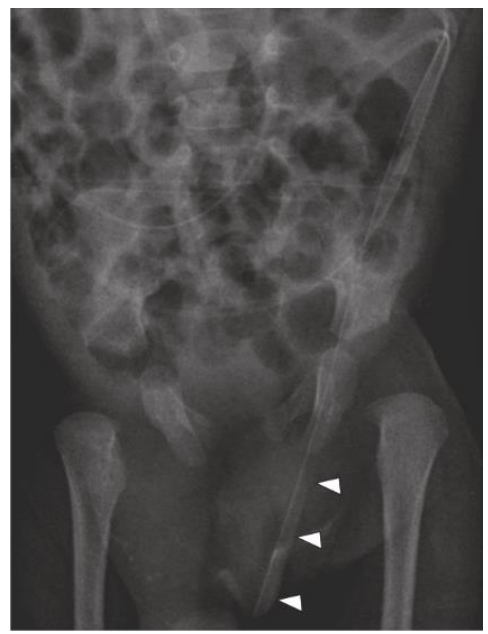

Figure 2. Plain X-ray showing the catheter path toward the scrotum (white arrows).

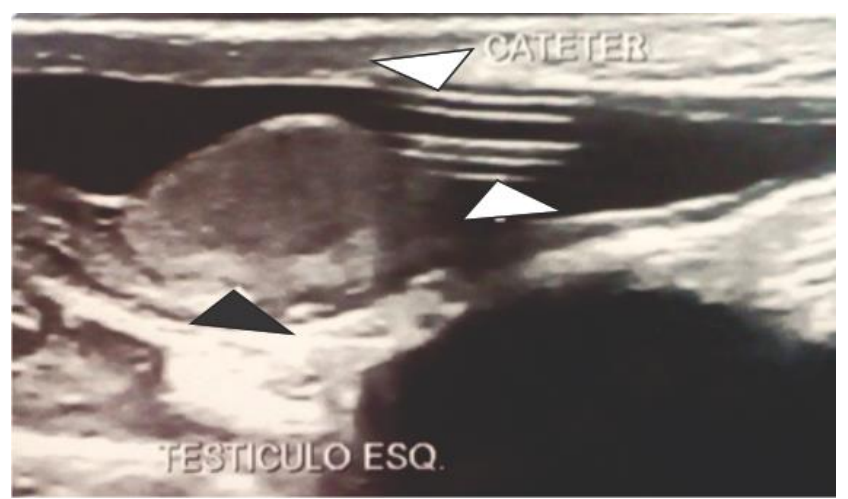

Figure. 3. Scrotal ultrasound showing the presence of the catheter (white arrows) near the left testicle (black arrow).

During hospitalization, the infant developed shunt dysfunction and infection. The shunt was withdrawn and treatment was initiated with vancomycin and cefepime. Cerebrospinal fluid (CSF) relief punctures were performed during the clinical treatment. Bilateral inguinal swelling during crying was noted and bilateral inguinal hernia was diagnosed. At the end of infection treatment, after 12 days of antibiotics and 3 negative CSF cultures, a new shunt was implanted. In addition, bilateral hernioplasty was performed by the pediatric surgery team.

The patient completed 14 days of antibiotics and was discharged in good condition. At follow-up, there was adequate head circumference growth and no testicular abnormalities.

\section{Discussion}

Similar published cases are summarized in table 1. The patients' age ranged from 4 days to 65 years, with 18 patients (54\%) being 1 -year-old or younger. The time interval between surgery and clinical presentation of the migration ranged from 24 hours to 4 years, with $27(81 \%)$ cases occurring within 12 months. The most common side of migration was the right-side, occurring in 23 patients (70\%). Scrotal swelling was the main clinical presentation, occurring in $84 \%$ of the patients. Nine $(27 \%)$ patients presented with hydrocephalus and $8(24 \%)$ cases with fever. In 5 $(15 \%)$ cases, the peritoneal catheter was fractured and released into the abdominal cavity.

The initial scan, in all cases, was a plain X-ray. The result was confirmed, in 5 cases, by ultrasound and, in 2 cases, by computed tomography of the abdomen. In 2 patients, there was an associated inguinal hernia. The most common treatment was repositioning of the peritoneal catheter, via inguinal (13 cases) or abdominal (5 cases) approach. In 26 patients (78\%), closure of procesus vaginalis - hernioplasty - was performed along with repositioning of the catheter.

The procesus vaginalis is formed from evagination of the peritoneum through the inguinal canal, giving way to the descent of the testis during the embryonic period. It is patent in approximately $80 \%$ of full-term children aged 2-16 years, and $15-30 \%$ of adults 6,7 . The patency of this structure is the predisposing anatomical condition for the occurrence of inguinal hernia, hydrocele and for the migration of the shunt catheter into the scrotum. VPS is associated with increased intra-abdominal pressure. This may delay the spontaneous closure of the vaginal process, related to the increased incidence of inguinal hernias and hydrocele, and may predispose migration of the distal catheter6,7. The presence of indirect inguinal hernia and catheter migration on the right-side is more common, likely because the right testicle descends later and the vaginal process remains patent for a longer period1. Another condition associated with catheter migration in infants under one year of age is the reduced volume of the peritoneal cavity at that age and the redundant length of the catheter7. However, these predisposing factors alone do not explain catheter migration, since they are found in most patients in this age group and migration is quite rare.

The present study reported a case of migration of VPS distal catheter to the scrotal region in which there was associated inguinal hernia, an event described in only 2 other cases. The affected side was also different from the most commonly reported side. The predominant clinical presentation and interval between surgery and migration were similar to those described in the literature. 
Table 1. Summary of previous reported cases of VPS scrotal migration

\begin{tabular}{|c|c|c|c|c|c|c|c|c|c|}
\hline Author & Case & Age & Interval & $\begin{array}{l}\text { Catheter } \\
\text { fracture }\end{array}$ & Side & Presentation & Image & Treatment & $\begin{array}{l}\text { Inguinal } \\
\text { Hernia }\end{array}$ \\
\hline Kwok et al ${ }^{8}$ & 1 & 6 months & 1 week & Yes & $\mathrm{B}$ & $\mathrm{S}$ & $\mathrm{XR}$ & $2,4,6$ & No \\
\hline Zvi Ram et a $\rho$ & 2 & 3 years & 2.5 years & No & $\mathrm{R}$ & $\mathrm{S}, \mathrm{H}$ & $\mathrm{XR}$ & $1,2,4,6$ & No \\
\hline Bristow et al ${ }^{10}$ & 3 & 10 months & 24 hours & No & $\mathrm{R}$ & $\mathrm{S}, \mathrm{F}$ & $\mathrm{XR}$ & $1,4,6$ & No \\
\hline Ward et al ${ }^{6}$ & 4 & 18 months & 7 months & No & $\mathrm{R}$ & $\mathrm{S}, \mathrm{H}, \mathrm{F}$ & $X R$ & 2,6 & No \\
\hline Fuwa et al ${ }^{11}$ & 5 & 1 year & 11 months & Yes & $\mathrm{L}$ & $\mathrm{S}, \mathrm{H}$ & XR & $2,5,6$ & No \\
\hline Lee et $a l^{1}$ & 6 & 65 years & 7 days & No & $\mathrm{R}$ & $\mathrm{S}$ & XR, US & 1,4 & No \\
\hline Ricci et al ${ }^{12}$ & 7 & 10 years & 2 years & Yes & $\mathrm{L}$ & $\mathrm{S}, \mathrm{H}$ & $\mathrm{XR}, \mathrm{CT}$ & $2,5,6$ & No \\
\hline Mohammadi et al ${ }^{3}$ & 8 & 7 months & 5 months & No & $\mathrm{R}$ & S & XR, US & 1,6 & No \\
\hline Calvario and Neto ${ }^{13}$ & 9 & 2 months & 1 month & No & $\mathrm{R}$ & S & $\mathrm{XR}$ & 3,6 & No \\
\hline Ozveren et al ${ }^{14}$ & 10 & 4 days & 24 hours & No & $\mathrm{R}$ & S & $\mathrm{XR}$ & 2,6 & No \\
\hline Kita et al ${ }^{15}$ & 11 & 5 years & 4 months & No & $\mathrm{L}$ & $\mathrm{S}$ & XR & 6 & No \\
\hline Karaosmanoglu et al ${ }^{16}$ & 12 & 14 months & - & - & $\mathrm{R}$ & $\mathrm{H}, \mathrm{F}$ & US, CT & - & No \\
\hline Elizabeth et $a^{17}$ & 13 & 14 months & 12 months & No & $\mathrm{R}$ & $\mathrm{F}$ & $\mathrm{XR}, \mathrm{US}$ & 3,6 & No \\
\hline Ho et al ${ }^{18}$ & 14 & 14 years & 12 months & Yes & $\mathrm{L}$ & $\mathrm{S}, \mathrm{F}$ & XR, US & $2,4,6$ & No \\
\hline Henriques et $a^{4}{ }^{4}$ & 15 & 5 months & 4 months & No & $\mathrm{R}$ & $\mathrm{S}$ & XR & 2,6 & Yes \\
\hline $\begin{array}{l}\text { Walsh and Kombogiorgas } \\
19\end{array}$ & 16 & 11 months & 6 months & No & $\mathrm{R}$ & $S$ & $\mathrm{XR}$ & - & No \\
\hline Garvia et al ${ }^{20}$ & 17 & 6 years & 5 years & No & $\mathrm{R}$ & $\mathrm{H}$ & $\mathrm{XR}$ & 6 & No \\
\hline Agarwal et al ${ }^{21}$ & 18 & 2 years & 7 months & No & $\mathrm{R}$ & S & $\mathrm{XR}$ & 2,6 & No \\
\hline Quintana-Schmidt et al ${ }^{22}$ & 19 & - & 1,5 month & No & $\mathrm{R}$ & $\mathrm{H}$ & $\mathrm{XR}$ & 2,6 & No \\
\hline Ramani ${ }^{23}$ & 20 & 6 months & 5 months & No & $\mathrm{R}$ & $\mathrm{S}$ & $\mathrm{XR}$ & 2,6 & No \\
\hline Rehm et al ${ }^{24}$ & 21 & 50 years & 4 years & No & - & $\mathrm{S}, \mathrm{H}$ & $X R$ & $1,4,5$ & No \\
\hline Panda et al ${ }^{25}$ & 22 & 5 years & 3.5 years & No & $\mathrm{L}$ & S & $\mathrm{XR}$ & 2,6 & No \\
\hline Shahizon et $a l^{2}$ & 23 & 14 years & 1 year & Yes & $\mathrm{L}$ & $\mathrm{S}, \mathrm{F}$ & $X R$, US & $2,4,6$ & No \\
\hline \multirow[t]{4}{*}{ Oktem et $a l^{5}$} & 24 & 10 months & 6 months & No & $\mathrm{R}$ & $\mathrm{S}$ & $\mathrm{XR}$ & 3,6 & No \\
\hline & 25 & 2.5 months & 5 months & No & $\mathrm{R}$ & S & $\mathrm{XR}$ & 3,6 & No \\
\hline & 26 & 9 days & 4 months & No & $\mathrm{R}$ & S & $\mathrm{XR}$ & 3,6 & No \\
\hline & 27 & 2.5 months & 24 hours & No & $\mathrm{R}$ & S & $\mathrm{XR}$ & 3,6 & No \\
\hline Ammar et $a l^{26}$ & 28 & 10 months & 2 months & - & $\mathrm{L}$ & $\mathrm{S}, \mathrm{F}$ & XR & 5 & No \\
\hline \multirow[t]{4}{*}{ Crofford and Balsam ${ }^{27}$} & 29 & 6 months & 5 months & No & $\mathrm{R}$ & $\mathrm{S}$ & $\mathrm{XR}$ & 3,6 & No \\
\hline & 30 & 3 months & 2 months & No & $\mathrm{R}$ & $S$ & $\mathrm{XR}$ & 3,6 & Yes \\
\hline & 31 & 5 months & 1 month & No & $\mathrm{R}$ & $\mathrm{S}$ & $\mathrm{XR}$ & - & No \\
\hline & 32 & 4 years & 2 months & No & $\mathrm{L}$ & $\mathrm{H}, \mathrm{F}$ & XR & 6 & No \\
\hline Shankar et al ${ }^{28}$ & 33 & 1 year & 11 months & No & $\mathrm{R}$ & $\mathrm{S}$ & $\mathrm{XR}$ & 3,6 & No \\
\hline
\end{tabular}

B - Bilateral; R - Right; L - Left; Presentation: S - Testicular swelling; H - Hydrocephalus; F - Fever; Image: XR - Radiography, US Ultrasound; CT - Computed tomography; Treatment: 1 - Repositioning of the catheter by abdominal route; 2 - Repositioning of the catheter by inguinal route; 3 - Repositioning by unspecified route; 4 - Decreased catheter length; 5 - 2; 6-Closure of the procesus vaginalis 


\section{Conclusion}

The presence of scrotal swelling in a patient with VPS should trigger the investigation of catheter migration. Diagnosis is necessary due to the complications such as testicle lesions and shunt dysfunction. Treatment must involve the repositioning of the distal catheter associated with the closure of the patent procesus vaginalis.

\section{Disclosures}

The authors report no conflict of interest concerning the materials or methods used in this study or the findings specified in this paper.

\section{References}

1. Lee BS, Vadera S, Gonzalez-Martinez JA. Rare complication of ventriculoperitoneal shunt. Early onset of distal catheter migration into scrotum in an adult male: Case report and literature review. Int J Surg Case Rep. 2015; 6:198-202.

2. Shahizon AM, Hanafiah M, Hing EY, Julian MR. Migration of a fractured ventriculoperitoneal shunt into the scrotum: a rare complication. BMJ Case Rep. 2013:12.

3. Mohammadi A, Hedayatiasl A, Ghasemi-Rad M. Scrotal migration of a ventriculoperitoneal shunt: a case report and review of literature. Med Ultrason. 2012;14(2):158-160.

4. Henriques JG, Pinho AS, Pianetti G. Complication of ventriculoperitoneal shunting: inguinal hernia with scrotal migration of catheter. Case report. Arq Neuropsiquiatr. 2003;61(2B):486-489.

5. Oktem IS, Akdemir H, Koç K, Menkü A, Tucer B, Selçuklu $A$, et al. Migration of abdominal catheter of ventriculoperitoneal shunt into the scrotum. Acta Neurochir. 1998;140(2):167-170.

6. Ward JF, Moquin RR, Maurer ST. Expanding the differential diagnosis of the acute scrotum: ventriculoperitoneal shunt herniation. Urology $2001 ; 58(2): 281$.

7. Grosfeld JL, and Cooney DR: Inguinal hernia after ventriculoperitoneal shunt for hydrocephalus. J Pediatr Surg. 1974 (9):311-316.

8. Kwok CK, Yue CP, Wen HL. Bilateral scrotal migration of abdominal catheters: a rare complication of ventriculoperitoneal shunt. Surg Neurol. 1989;31(4):330331.

9. Ram Z, Findler G, Guttman I, Cherniak R, Knoller N, Shacked I. Ventriculoperitoneal shunt malfunction due to migration of the abdominal catheter into the scrotum. J Pediatr Surg. 1987;22(11):1045-1046.

10. Bristow DL, Buntain WL, James HL. Ventriculoperitoneal (VP) shunt migration causing an acute scrotum: a case report of Doppler evaluation. J Pediatr Surg. 1978;13(6):538-539.

11. Fuwa I, Matsukado Y, Itoyama $Y$, Yokota A. Migration of a dissected peritoneal shunt catheter into the scrotum. Brain Dev. 1984;6(3):336-338.
12. Ricci C, Velimirovic BM, Fitzgerald TN. Case report of migration of 2 ventriculoperitoneal shunt catheters to the scrotum: Use of an inguinal incision for retrieval, diagnostic laparoscopy and hernia repair. Int J Surg Case Rep. 2016; 29:219-222.

13. Calvário JS, Paglioli Neto E. Hydrocele following placement of a ventriculoperitoneal shunt: case report. Arq Neuropsiquiatr. 1990;48(1):113-115.

14. Ozveren MF, Kazez A, Cetin H, Ziyal IM. Migration of the abdominal catheter of a ventriculoperitoneal shunt into the scrotum--case report. Neurol Med Chir. 1999;39(4):313-315.

15. Kita D, Hayashi Y, Kinoshita M, Ohama K, Hamada $J$. Scrotal migration of the peritoneal catheter of a ventriculoperitoneal shunt in a 5-year-old male. Case report. Neurol Med Chir. 2010;50(12):1122-1125.

16. Karaosmanoglu D, Metin Y, Akata D, Haliloglu M. An unusual cause of hydrocele: malpositioned ventriculoperitoneal shunt in the scrotum. J Ultrasound Med. 2008;27(1):159-160.

17. Elizabeth KE, Devakumar VK, Famesh A. Unusual Migration of VP Shunt. Indian Pediatr. 2013;50(4):435.

18. Ho CC, Jamaludin WJ, Goh EH, Singam P, Zainuddin ZM. Scrotal mass: a rare complication of ventriculoperitoneal shunt. Acta Medica. 2011;54(2):8182.

19. Walsh AR, Kombogiorgas D. Coiled ventricularperitoneal shunt within the scrotum. Pediatr Neurosurg. 2004;40(5):257-258.

20. Rivero-Garvía M, Barbeito Gaído JL, Morcillo J, Márquez Rivas J. Shunt dysfunction secondary to peritoneal catheter migration to the scrotum. Arch Argent Pediatr. 2013;111(1):14-16.

21. Agarwal T, Pandey S, Niranjan A, Jain V, Mishra S, Agarwal V. Unusual complication of ventriculoperitoneal shunt surgery. J Pediatr Neurosci. 2009;4(2):122-123. 22. Quintana-Schmidt C, Laria PC, Folch MT, Calderón EM, Rodríguez RR. Scrotal migration of ventriculoperitoneal shunts. An Pediatr. 2010;73(4):219221.

23. Ramani PS. Extrusion of abdominal catheter of ventriculoperitoneal shunt into the scrotum. Case report. J Neurosurg. 1974;40(6):772-773.

24. Rehm A, Bannister CM, Victoratos G. Scrotal perforation by a ventriculoperitoneal shunt. $\mathrm{Br} J$ Neurosurg. 1997;11(5):443-444.

25. Panda SS, Singh A, Bajpai M, Sharma N. Shunt in scrotum: unusual complication in operated cases of hydrocephalus. BMJ Case Rep. 2013:1-2.

26. Ammar A, Ibrahim AW, Nasser M, Rashid M. CSF hydrocele--unusual complication of $\mathrm{V}-\mathrm{P}$ shunt. Neurosurg Rev. 1991;14(2):141-143.

27. Crofford MJ, Balsam D. Scrotal migration of ventriculoperitoneal shunts. AJR Am J Roentgenol. 1983;141(2):369-371.

28. Shankar B, Narayanan R, Paruthikunnan SM, Kulkarni CD. Scrotal migration of ventriculoperitoneal shunt. BMJ Case Rep. 2014:1-2. 